\title{
Erythrocyte membrane microviscosity and phospholipid composition in lead workers
}

\author{
L R COOK, S J STOHS, C R ANGLE, T I HICKMAN, R C MAXELL
}

From the Toxicology Program and the Departments of Pediatrics and Pharmaceutical Sciences, University of Nebraska Medical Center, Omaha, NE 68105, USA

ABSTRACT The microviscosity and fluidity of erythrocyte ghost membranes from lead workers and control subjects was measured by fluorescence polarisation using the fluorophore, 1,6-diphenyl-1,3,5-hexatriene (DPH). Increased blood lead was associated with a significant decrease in the average microviscosity of resealed and unsealed erythrocyte membranes. Since DPH fluorescence reflects the organisation of lipids in the central core of the membrane, two aspects of phospholipid metabolism were investigated. Phospholipids were extracted from red blood cell ghost membranes and identified by high performance liquid chromatography. The ratio of phosphatidyl choline to phosphatidyl ethanolamine, an established correlate of membrane fluidity, was significantly increased in lead workers. This is attributed to the known increases in red blood cell cholesterol in lead workers and the structural incompatibility of phosphatidyl ethanolamine and cholesterol, which result in a compensatory increase of phosphatidyl choline. Erythrocyte ghost membranes from control subjects were resealed with the intermediates in phospholipid synthesis that increase with a lead inhibited decrease in red blood cell pyrimidine $5^{\prime}$-nucleotidase. Membrane fluidity was not modified by incubation with cytidine triphosphate, uridine triphosphate, cytidine diphosphate choline, or cytidine diphosphate ethanolamine. Alterations in the microviscosity of the lipid regions of the hydrophobic core of the erythrocyte membrane bilayer and in the phospholipid composition of the membrane may be defects which contribute to the clinical and biochemical instability of the red blood cell on exposure to lead.

Mechanisms that produce shortened red blood cell (RBC) survival, increased shear viscosity, and a decrease of osmotic fragility in erythrocytes from lead workers are incompletely defined. Fukumoto et al found that lead modifies the percentage of globular proteins that affect membrane ion transport or fluidity. ${ }^{1}$ Conformational changes in the proteins of the RBC membrane believed responsible for sodium/potassium ATPase function were reported by Selhi et al. ${ }^{2}$ Using erythrocyte membranes and electron spin resonance with a 16-doxyl-stearate label to probe the inner core of the RBC membrane, Valentino et al found a decrease in membrane fluidity associated with exposure to lead and attributed this to changes in membrane protein or to the increased cholesterol. ${ }^{3}$

The present study of the effects of lead exposure on RBC membrane used 1,6-diphenyl-1,3,5-hexatriene (DPH) fluorescence as a primary index of alterations

Accepted 9 March 1987 in membrane lipids of the central core and examined its relation to blood lead and to phospholipid composition of the membranes. We also tested the in vitro effect of loading and sealing erythrocyte ghost membranes with the pyrimidine nucleotides and esters that accumulate in RBC with lead induced inhibition of pyrimidine $5^{\prime}$-nucleotidase and are known intermediates in phospholipid metabolism.

\section{Subjects}

All subjects were adult white men aged 24-45 who were employed as lead workers (PbW) or in health care (C). Informed consent was provided under a protocol approved by the University of Nebraska Medical Center review board.

\section{Methods}

\section{BLOOD LEADS}

Heparinised venous blood was collected in lead free vacutainer tubes (Becton, Dickinson, Rutherford, 
$\mathrm{NJ}$ ). Ten microlitre aliquots of whole blood diluted in $\mathrm{NH}_{4} \mathrm{H}_{2} \mathrm{PO}_{4}$ and Triton X-100 were assayed in duplicate using a Perkin Elmer 2380 atomic absorption spectrophotometer with a graphite furnace. ${ }^{4}$

\section{MEMBRANE PREPARATION}

$A$ Unsealed ghosts ${ }^{5}$-All procedures were performed at $0-4^{\circ} \mathrm{C}$. Saline $(0.9 \% \mathrm{NaCl}$ solution $)$ washed, packed red cells were lysed with 20 volumes $5 \mathrm{mM}$ sodium phosphate, $\mathrm{pH} 8$. The resulting erythrocyte membrane ghosts were centrifuged at $15000 \mathrm{rpm}$ for $15-20$ minutes and the supernatant removed by aspiration. The membrane pellet was resuspended in phosphate buffer and recentrifuged at $15000 \mathrm{rpm}$ for $15-20$ minutes. This washing procedure was repeated at least three times to produce colourless ghosts.

$B$ Sealed right side out ghosts-Buffer loaded unsealed ghosts (see A) were resuspended in 40 volumes of phosphate buffered saline $(150 \mathrm{mM} \mathrm{NaCl}$, $5 \mathrm{mM}$ sodium phosphate, $\mathrm{pH} 8$ ) and incubated at $37^{\circ}$ for 40 minutes. $^{5}$ The ghosts were pelleted and washed twice with phosphate buffered saline before fluorescence polarisation measurements.

\section{NUCLEOTIDE LOADING}

Three hundred microlitres of unsealed erythrocyte membrane ghosts (see A) were suspended in $700 \mu 1$ $50 \mathrm{mM}$ Tris/glycylglycine buffer, $\mathrm{pH} 8$, containing $5 \mathrm{mM} \mathrm{MgCl}, 1270 \mu \mathrm{M}$ ATP, and the following nucleotides: CTP $770 \mu \mathrm{M}$; UTP $590 \mu \mathrm{M}$; CDP-C $930 \mu \mathrm{M}$, and CDP-E $410 \mu \mathrm{M}$. All concentrations were comparable to those in congenital deficiency of pyrimidine $5^{\prime}$-nucleotidase. ${ }^{6}$ Reaction mixtures were held for 14-16 hours at $4^{\circ} \mathrm{C}$ and then incubated one hour in a shaking water bath at $37^{\circ} \mathrm{C}$. The resealed ghosts or vesicles were washed with 10 volumes of a solution containing $150 \mathrm{mM} \mathrm{NaCl}, 10 \mathrm{mM}$ Tris- $\mathrm{HCl}$, $\mathrm{pH} 8$, and $5 \mathrm{mM} \mathrm{MgCl}_{2}$. Vesicles were pelleted at $15000 \mathrm{rpm}$ and the supernatant aspirated before microviscosity measurements. ${ }^{7}$

\section{PROTEIN DETERMINATION}

Suspensions of membrane ghosts were diluted to obtain protein concentrations suitable for assay. One hundred microlitres of diluted membrane suspensions and bovine serum albumin as standards were incubated with $100 \mu 10 \cdot 1 \mathrm{~N} \mathrm{NaOH}$ for one hour at $37^{\circ} \mathrm{C}$. Bio-Rad protein reagent (Bio-Rad, Richmond, CA), $5 \mathrm{ml}$, was added and absorbance at $595 \mathrm{~nm}$ was used to determine protein concentrations. ${ }^{8}$

\section{FLUORESCENCE POLARISATION}

RBC membrane microviscosity was measured by the method of Shnitzky and Barenholz. ${ }^{9}$ Three microlitres of $\mathrm{DPH}$, in $0.001 \mathrm{M}$ tetrahydrofuran, were mixed with $3 \mathrm{ml}$ degassed membrane buffer. Fifteen microlitres of membrane suspension were added, followed by gentle mixing. Fluorescence polarisation measurements were carried out at $25^{\circ} \mathrm{C}$ using a Perkin ? Elmer LS-5 fluorescence spectrophotometer. $\vec{F}$ Excitation and emission wavelengths were 330 and $449 \mathrm{~nm}$, respectively. Recordings were made of fluorescence intensities parallel $\left(\mathrm{I}_{\mathrm{ij}}\right)$ and perpendicular $\left(I_{j}\right)$ to the direction of the polarisation of the exciting light. Calculations were made of fluorescence anisotropy, $r$, where $r=\frac{I_{i i}-1_{i}}{I+2}$ and the anisotropy parameter, ap $=\left[\frac{r_{o}}{r}-1\right]^{-1}$, which provides a similar index of the resistance to rotational motion. The greater the ap the higher the microviscosity of the environment. ${ }^{10}$ The term $r_{0}$ has an experimental value of 0.362 for DPH.

\section{PHOSPHOLIPID ANALYSIS}

One hundred microlitres of resealed membranes (buffer loaded) were extracted with $2 \mathrm{ml}$ 을 chloroform/methanol/2 M HCl (6:3:1). The chloroform layer was separated and the aqueous layer reextracted twice with $2 \mathrm{ml}$ chloroform/methanol (2:1). The combined chloroform extracts were dried under nitrogen. Lipid was resuspended in 25-34 $\mu$ l hexane and injected into a Beckman (Berkeley, CA) chromatographic system consisting of two model 110 pumps, a model 420 microprocessor (Beckma Instruments, Palo Alto, CA) and Partasil 10 SA anion exchange columns with a UV detector (Labora tory Data Control, River Beach, FL) operating at $206 \mathrm{~nm}$. Phospholipids were eluted by high performance liquid chromatography using a continuous gradient from $100 \%$ solvent A (hexane, propanol, water-6:8:0.75) to $100 \%$ solvent $B$ (hexane, propanol, $\left.\mathrm{H}_{2} \mathrm{O}-6: 8: 1 \cdot 5\right) .^{11}$ The separation into phosphatidyl ethanolamine (PE), phosphatidyl inositol (PI), phosphatidyl serine (PS), and phosphatidyl choline (PC) took 18 minutes.

\section{STATISTICAL ANALYSIS}

The SAS program (SAS Institute Inc, Cary, NC) was used to calculate $t$ tests for significant difference, $\mathrm{F}$ tests for analysis of variance (ANOVA), and univariate and bivariate regressions for multiple measurements on the same subjects. Data are presented throughout as the mean \pm the standard deviation. Blood lead values were logarithmically transformed because they were not normally distributed.

\section{Results}

RBC membrane viscosity, expressed as the anisotropy parameter (ap) of membrane fragments, was 
Table 1 Anisotropy parameter (ap) of red blood cell membrane fragments

\begin{tabular}{|c|c|c|}
\hline & $\begin{array}{l}\text { Lead workers } \\
(n=6)\end{array}$ & $\begin{array}{l}\text { Controls } \\
(\mathrm{n}=5)\end{array}$ \\
\hline $\begin{array}{l}\text { Blood lead }(\mu \mathrm{M}) \\
\text { Anisotropy parameter } \\
{ }^{*} \mathrm{p}<0.05 \text { by } t \text { test. }\end{array}$ & $\begin{array}{l}1.54 \pm 0.47 \\
1.96 \pm 0.54\end{array}$ & $\begin{array}{l}0.39 \pm 0.13^{*} \\
2 \cdot 70 \pm 0.27^{*}\end{array}$ \\
\hline \multicolumn{3}{|c|}{$\begin{array}{l}\text { Effect of storage of mean ap of } R B C \text { fragments of } 2 \text { lead workers: } \\
\text { ap (fresh) } \\
\text { ap }(24 \mathrm{~h})\end{array}$} \\
\hline ap for $\mathrm{DPH}=\left[\frac{0.362-1}{\mathrm{r}}\right.$ & ]$^{-1}$ & \\
\hline
\end{tabular}

significantly lower in six lead workers with $\mathrm{PbB} 1.54$ $\pm 0.47 \mu \mathrm{M}$ than in normal controls (table 1). Storage for 24 hours at $4^{\circ} \mathrm{C}$ had the expected effect of increasing viscosity or decreasing fluidity. The unexpected finding of a decreased viscosity of the $\mathrm{RBC}$ membrane fragments from $\mathrm{PbW}$ was confirmed in assays of the ap of fresh, haemoglobin free resealed RBC ghosts from 25 lead workers with blood lead $(\mathrm{PbB}) 0.86$ to $2 \cdot 1 \mu \mathrm{M}$ and 23 age matched male controls with $\mathrm{PbB} 0.17$ to $0.39 \mu \mathrm{M}$ (table 2). The ap is modified by the protein content of the assay but protein concentrations were eqivalent. The bivariate regression equation for ap with $\log \mathrm{PbB}\left(\mathrm{r}^{2}=0.29\right)$ and protein content $\left(r^{2}=0.09\right)$ was consistent with the significantly lower $(p<0.0001)$ ap of $\mathrm{PbW}$ than $\mathrm{C}$, independent of protein concentration.

There was no change in the microviscosity of haemoglobin free $\mathbf{R B C}$ ghosts from control subjects after one hour or 24 hours incubation with adenosine triphosphate (ATP) or with ATP plus the pyrimidine nucleotides and their esters at concentrations found in the RBC of a subject with $15 \%$ of normal activity of pyrimidine 5 '-nucleotidase. ${ }^{6}$

Since an increased RBC cholesterol:phospholipid ratio has been repeatedly established as typical of lead exposure, ${ }^{3}$ we were primarily interested in the effect of $\mathrm{PbB}$ on the concentrations and ratio of the major phospholipids of the RBC membranes. In replicate HPLC assays of RBC membrane phospholipid there was a significant increase $(p<0.0001)$ in the phos-
Table 2 Anisotropy parameter (ap) of resealed, haemoglobin free red blood cell ghosts

\begin{tabular}{lll}
\hline & $\begin{array}{l}\text { Lead workers } \\
(n=25)\end{array}$ & $\begin{array}{l}\text { Controls } \\
(\mathrm{n}=23)\end{array}$ \\
\hline Blood lead $(\mu \mathrm{M})$ & $1.38 \pm 0.33$ & $0.29 \pm 0.06^{*}$ \\
Anisotropy parameter & $1.54 \pm 0.15$ & $2.03 \pm 0.56^{* *}$ \\
Protein content $(\mathrm{mg} / \mathrm{ml})$ & $0.97 \pm 0.42$ & $0.94 \pm 0.35$
\end{tabular}

${ }^{*} \mathrm{p}<0.01$ by $t$ test; ${ }^{* *} \mathrm{p}<0.0001$ by F ratio, ANOVA.

The multiple regression for the bivariate correlation of ap with $\mathrm{PbB}$ and the protein concentration of each sample was:

ap $=2.8237-0.6234 \log 10 \mathrm{PbB} \mu \mathrm{g} / \mathrm{dl}-0.3600 \mathrm{mg} / \mathrm{ml}$ protein

$\mathrm{r} 2 \log \mathrm{PbB}: 0 \cdot 29$, SEE 0.4753; $\mathrm{r} 2$ protein concentration:0.09, SEE

$0 \cdot 3021$; $r 2$ total: $0 \cdot 37$; adjusted $\mathrm{r} 2$ total:0.34

phatidyl choline: phosphatidyl ethanolamine (PC:PE) ratio of $\mathrm{PbW}$ (table 3). $\mathrm{RBC}$ membrane viscosity, here normalised as the fluidity index (FI) or ap per $\mathrm{mg}$ protein, was $2.6 \pm 0.71 \mathrm{PbW}$, and $3.6 \pm 1.1$ in $10 \mathrm{C}$. The decreased $R B C$ viscosity of the $\mathrm{PbW}$ was consistent with earlier assays; the lack of statistical significance is attributed to the relatively low $\mathrm{PbB}$, ranging from 0.85 to $1.62 \mu \mathrm{M}$ in $\mathrm{PbW}$.

\section{Discussion}

Changes in the rheological properties of the RBC after lead exposure such as increased blood viscosity and decreased deformability are well documented but not well understood. ${ }^{1-3}$ Studies have shown that alterations in the protein cytoskeleton or lipid composition of erythrocyte membranes can affect membrane fluidity or microviscosity and ultimately the macroviscosity or flow properties of the RBC. ${ }^{1212}$

In this study membrane fluidity was examined through the technique of fluorescence polarisation. Fluorophores such as DPH, which are immobilised in the hydrophobic core of a membrane and excited by polarised light, will emit fluorescence that may be interpreted through the ap $\left[\frac{r_{0}}{r}-r\right]^{-1}$, (see fluorescence polarisation under methods). The greater the value of this parameter, the higher the apparent "microviscosity" of the environment. The present studies were undertaken to characterise the

Table 3 Phospholipid ratios of red blood cell ghosts

\begin{tabular}{|c|c|c|}
\hline & Lead workers $(n=12)$ & Controls $(n=10)$ \\
\hline $\begin{array}{l}\text { Blood lead }(\mu \mathrm{M}) \\
\text { Phosphatidyl choline: phosphatidyl ethanolamine } \\
\text { Phosphatidyl ethanolamine: phosphatidyl inositol } \\
\text { Phosphatidyl ethanolamine: Phosphatidyl serine } \\
\text { Phosphatidyl inositol: phosphatidyl serine } \\
\text { Fluidity index }\end{array}$ & $\begin{array}{l}1.17 \pm 0.27 \\
2.00 \pm 0.69 \\
0.74 \pm 0.29 \\
0.96 \pm 0.37 \\
1.7 \pm 0.87 \\
2.6 \pm 0.71\end{array}$ & $\begin{array}{l}0.32 \pm 0.12^{*} \\
1.10 \pm 0.21^{* *} \\
0.78 \pm 0.58 \\
1.10 \pm 0.22 \\
1.7 \pm 0.57 \\
3.6 \pm 1.1\end{array}$ \\
\hline
\end{tabular}

${ }^{*} \mathrm{p}<0.01$ by $\mathrm{t}$ test; ${ }^{* *} \mathrm{p}<0.0001$ by $\mathrm{F}$ ratio, ANOVA.

Fluidity index $=a p / m g$ protein. 
microviscosity of the non-polar regions of the erythrocyte ghost membranes. The demonstrated decrease in the microviscosity is interpreted as a perturbation in the lipid organisation of the central core of the bilayer.

Membrane fluidity as determined by fluorescence polarisation is distinct from assessment by electron spin resonance (ESR), nuclear magnetic resonance, and other techniques, which better define the interactions of lipids with aqueous components, other lipids and proteins, the rotational and lateral mobility of proteins, and the effects of divalent cations. ${ }^{13}$ Valentino et al found a modest decrease in the fluidity of RBC from PbW when measured by ESR with 5 doxyl-stearate (5NS) and 16 doxyl-stearate (16NS). ${ }^{3}$ There was a greater increase in viscosity of the inner core (16 NS) than the outer layer but no significant direct correlation with $\mathrm{PbB}$ which ranged from 2.5 to $3.9 \mu \mathrm{M}$, considerably higher than that of our subjects. Fiorini et al found an effect on the ESR of 16 NS in liposomes incubated with $2 \cdot 85-11.5 \mu \mathrm{M} \mathrm{Pb}^{++} .14$ The effect of high concentrations of in vitro $\mathrm{Pb}^{++}$on ESR viscosity is attributed to an increase in charge density of the central core and intramembranous aggregation of membrane bound proteins.

Decreases in microviscosity as measured by the fluorescence polarisation of DPH are primarily related to cholesterol depletion, to the length and unsaturation of the fatty acid ester chains in phospholipids, and to increases in the relative amount of phosphatidylcholine expressed either as the PC:PS ratio $^{9}$ or the PC:PE ratio. ${ }^{7}$

Given the characteristics of DPH fluoresence as an index of fluidity, we propose that the increase in PC and the direct correlation of a decrease in DPH viscosity with $\mathrm{PbB}$ relate to the well established increase of RBC cholesterol in PbW. ${ }^{3}$ Both PE and cholesterol have truncated cone shapes that are structurally incompatible. ${ }^{15}$ This results in a preferential association with PC in PC-PE cholesterol mixtures and is why high amounts of $\mathrm{PE}$ and cholesterol do not occur in the same membrane. ${ }^{13} \mathrm{~A}$ similar association of high PC and cholesterol is found in the RBC membranes of lecithin:cholesterol acyl transferase deficiency and in hereditary haemolytic anaemia with high red cell membrane phosphatidyl choline. ${ }^{16}$

Decreased microviscosity as measured by DPH does not contradict the increased macroviscosity of the $\mathrm{RBC}$ in $\mathrm{PbW}$. It is an index of alterations in the rotational mobility of lipids in the central hydrophobic core of the bilayer that may well contribute to the haemolytic effects of lead exposure.

This research was supported by USPHS grant RO1

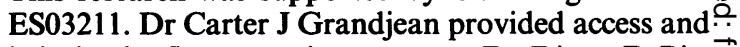
help in the fluorometric measures. Dr Diane D Birt $\vec{F}$ and Mr Alan D Julius provided similar support for the phospholipid assays. Ms Donna Kuntzelman was $\frac{\mathrm{C}}{\mathrm{O}}$ clinical coordinator.

\section{References}

1 Fukumoto K, Karai I, Horiguchi S. Effect of lead on erythrocyte membranes. Br J Ind Med 1983;40:220-3.

2 Selhi HS, White JM. The effect of lead on the red cell membrane. Postgrad Med J 1975;51:765-9.

3 Valentino M, Fiorini RM, Curatola G, Governa M. Changes of $\frac{\mathbb{D}}{3}$ membrane fluidity in erythrocytes of lead-exposed workers. Int Arch Occup Environ Health 1982;51:105-12.

4 Fernandez F, Hilligoss D. An improved graphite furnace method for the determination of lead in blood using matrix N modification and the L'Vov platform. Atomic Spectroscopy 1982;3:130-1.

5 Steck TL, Kant JA. Preparation of impermeable ghosts 응 and inside-out vesicles from human erythrocyte membranes. Methods Enzymol 1974;31:172-80.

6 Swanson MS, Markin RS, Stohs SJ, Angle CR. Identification of cytidine diphosphodiesters in erythrocytes from a patient with pyrimidine nucleotidase deficiency. Blood 1984;63:665-70.

7 Hirata F, Axelrod J. Enzymatic methylation of phosphatidylethanolamine increases erythrocyte membrane $\frac{\mathbb{D}}{-}$ fluidity. Nature 1978;275:219-20.

8 Simpson I, Sonne O. A simple, rapid and sensitive method $\operatorname{Br} \overrightarrow{0}$ measuring protein concentration in subcellular fractions pese pared by sucrase density ultracentrifugation. Anal Biochem 1982;119:424-7.

9 Shinitzky M, Barenholz Y. Fluidity parameters of lipid regiơrs determined by fluorescence polarisation. Biochim Biophys Acta $\bar{\partial}$ 1978;515:367-94.

10 Schachter D, Shinitzky M. Fluorescence polarisation studies of $\frac{2}{\mathrm{D}}$ rat intestinal microvillus membranes.J Clin Invest 1977; 으 59:536-48.

11 James JL, Clawson GA, Chan CH, Smuckler EA. Analysis of the $\frac{\bar{\partial}}{\overline{3}}$ phospholipid of the nuclear envelope and endoplasmic reticulum of liver cells by high pressure liquid chro-? matography. Lipids 1981;16:541-5.

12 Chabanel A, Flamm M, Sung K, Lee M, Schachter D, Chien S. Influence of cholesterol content on red cell membrane $\mathbb{D}$ viscoelasticity and fluidity. Biophys $J$ 1983;44:171-6.

13 Benga G, Holmes R. Interactions between components in biolog- $\bar{\sigma}$ ical membranes and their implications for membrane function. Prog Biophys Mol Biol 1984;43:195-257.

14 Fiorini RM, Curatola G, Valentino M, Governa M. Effect of lead $\frac{0}{3}$ on physical state of erythrocytes and model membranes. Boll Soc Ital Biol Sper 1982;58:871-5.

15 VanDijck PW. Negatively charged phospholipids and their position in the cholesterol affinity sequence. Biochim Biophys Acta $\frac{D}{0}$ 1979;555:89-101.

16 Yawata $\mathrm{Y}$. Recent progress in research on red cell membrane $\mathrm{N}$ disorders in Japan. Acta Haematologica Japan 1983;46: G 1426-40. 